\title{
Diasporic Dilemma: A Quest for Identity and Security in Naipaul's A House for Mr. Biswas
}

\author{
Dr. Nitesh Kumar Baunthiyal, \\ Assistant Professor, Department of Humanities, DIT University Dehradun, Uttarakhand, India
}

In A House for Mr. Biswas, Naipaul describes the search for identity and security of a protagonist who lives in an unstructured social milieu. The novel describes the experience of an expatriate of Trinidad via various places and to the Port of Spain. The life of the protagonist Mohan Biswas reflects the dilemma of a detached immigrant whose entire life passes in a desire to find his roots and to attain an authentic identity in the society. The life of Mr. Biswas also replicates the life of Naipaul, whose experience of exile reflects the unquenched need of identity. In the name of Mr. Biswas, author gets a way to trace his experiences of nonidentity. The prologue of novel reflects the truth of Mr. Biswas's life:

How terrible it would have been, at this time, to be without it: to have died among the Tulsis, amid the squalor of that large, disintegrating and different family; to have left Shama and children among them, in one room; worse, to have lived without even attempting to lay claim to one's portion of the earth; to have lived and died as one had been born, unnecessary and unaccomodated (HMB 8).

The words clearly suggest that the text is about to prove an individual's self that maters in the society within life and after death. In Mr. Biswas, this quest to prove himself among family and Tulsi-estate remains continue from birth to death. The novel begins with the description of the unlucky birth of Mr. Biswas, who unusually born with six fingers in one hand and becomes a victim of traditional beliefs. Unlike a child, he does not receive affection of family but his childlike activities are restricted at home as pundit predicts his unlucky charm for the family and mainly for father. Thus, an 'ominous child' becomes his first identity that made him a confined self within a family. This is the fate that the prediction by the pundit proves when in searching of Mr. Biswas, his father Raghu dives into the pool and died. His second identity comes in the society as a boy who, ". . . has eaten up his own father" (28). This stigma becomes the identity of Mr. Biswas that drives his mind in different directions and shapes his despairing sensibility which, ". . . carry about them the mark in their attitudes sensibilities, and convictions of the slave, the unnecessary man" (Walsh VSN 71). After being sold the house to the neighbor, Dhari under compulsions, the family moves to his mother's sister Tara's muddy hut in where, "For the next thirty-five years he was to be a wanderer with no place he could call his own, with no family ..." (38).

In the childhood, Mr. Biswas lives in his mother's sister Tara house and later moves to Tulsi house in Arwacas as a sign painter. There he meets Shama, falls in love, and marries to her. This is the first real phase in Biswas's life from where his actual search for identity and security begins. He has to live in Tulsi-dom with others sons in laws', where he, “... felt trapped" (92). This perpetual feeling of aloof arouses a sense of 'quest' for identity, while this 'trap' compels his soul to find way to emancipate from Tulsi's estate. He becomes an unwanted insider in Tulsi family and confined by its powerful social and economic strata, "in the High Street at Arwacas, Hanuman House stood like an alien White fortress" (81). In Hanuman House, he finds himself, “. . . indifference rather than hostility" (195). Tulsi family is rich and powerful which provides Mr. Biswas jobs and opportunities but his un-belongingness makes him unable to normalize with them as he is an unwanted outsider for Tulsi family; his living style and family condition was quite differing than that of Tulsis'. This is the constant dilemma in Mr. Biswas's life, that a world, where he enters, “. . . everything beyond its gate was foreign and unimportant” (195). He feels inferior among family members and, “. . when everyone worked with energy and joy enthusiasm reacting upon enthusiasm in him he remains aloof" (195).

In the life of Mr. Biswas, 'House' is the entrenched wish and symbol of identity as it is in Naipaul's life too. The search of protagonist to get a house is the chief motif in the novel that reflects the primal wish of every individual for a safe haven in form of a house. This search of Mr. Biswas for house also symbolizes the fulfillment of belongingness and a prerequisite for a social identity. This is why, "The House in this novel is a symbol not for rootedness but for freedom from slavery and oppression" (Das 102). From birth Biswas lacks his own house and other houses where he moved on, were, “. . . bare,spacious, unpainted wooden house . . . (49). 
Tulsi first provides Mr. Biswas a village, Chase for managing a shop and a house. Alike displaced person, Biswas entire life struck with a question of this house, “. . . was it his own?" (156). On the opening ceremony of shop at Chase, Mr.Biswas, ". . . found himself a stranger in his own yard" (156). His feeling of belongingness to the shop is shattered when he noticed that family members, ". . . called the shop the Tulsi shop even after he had painted a sign and hung it above the door" (156). Mr. Biswas is a victim of homelessness and non-identity who efforts for settlement, but his insecure self becomes the causes of recurrent failure. His every return to his mother at Pagotes during living at Chase reminds the suffering of mud hut, as he is the only child who had spent most of the times with her. Seeing her condition, "Dutifully he put his arm around her. The gesture caused him pain, making him feel his own worthlessness" (199). Similarly the house at 'Chase' seems to him disordered, cold, and abandoned. Mr. Biswas's next misadventure begins, when Tulsi sends him to the barracks of Green Vale as a driver at the minimum salary and compelled to live among workers in shared rooms. This is the second time when the fear of social -insecurity generates as the place, “. . dump and shadowed and close" (214). This experience propels him to feel like every individuals in the world, "... . decided that time had come for him to build his house" (214).

Biswas's earlier experience of mud hut infuses hatred feeling for imperfect house, "He didn't want mud for walls earth for floor tree branches for rafters and grass for roof" (219) and the list is long of contempt for muddy house because he dreams, “. . . a real house made with real materials" (219). The wish of perfection can be seen when he presents a doll's house to his daughter Savi in which he visualizes, "Every room of the doll's house was daintily furnished" (224). The doll's house also symbolizes Biswas's extreme wish for freedom and security as well as fulfillment of a dream for a perfect abode. He strives to face the challenges to build house at Green Vale which starts with continual delays and finally burnt by workers. Every failure in the outer world propels him to return back to rich Tulsi, but it could not solve his problems of security and identity. The quest of Mr. Biswas's journey towards attaining identity, and security as Robert Hamner observes:

After Green Vale all the evasive reaction here to fore signs of his inadequacy and weakness, undergoes marked change. He continues to rage and throw impotent pamper tantrums, but upon his recovery at Hanuman House he has gained valuable confidence in the resilience of the spirit (CS 228).

Recovering himself from the trauma of Green Vale, Mr. Biswas moves to Port of Spain to prove himself. He gets a job of reporter in the Sentinel. Thus, the city Port of Spain becomes the place of Mr. Biswas's to attain a professional identity. His earlier life at Hanuman Houses passes without asserting his identity and security because he was lost among stranger group of people, but in Port of Spain, “. . . he saw the city as made up of individual, each of whom had his place in it"(332). There, he emerges as a famous creative writer whose photograph appears frequently in news papers and magazines; this achieving status helps him to, “. . . recover his family" (345) from Mrs. Tulsi. But his new job of writing does not lessen the feeling of alienation in him. The protagonists of his stories undergo same experiences as he had in past, "The hero trapped into marriage, burdened with a family" (363). The appetite, hopes and desires of his protagonists reflect Mr. Biswas's past dilemma and indirectly experienced by Naipaul himself. He begins stories with interest and joy, but, ". . . left him dissatisfied and feeling unclean" (363). His stories highlight the plight of 'lost identity' and his writing represents the ways of self-realization to fulfill the quest of identity. Thus, the insecurity faced by Mr. Biswas is a natural conformity with all human being faced in general in an alien land dominated by colonized society.

Mr. Biswas's quest for security also related with the relations he manages in the family. Shama and childrens's recurrent displeasure to live with him has always been a cause of deep depression. Shama's constant returning habit to Hanuman House signifies her fear of identity and insecurity, at Chase, Shama shouts at Mr. Biswas, ". . . give up the shop and return to Hanuman House" (199). She always calls Hanuman House 'home' and happy to live with Tulsi. His two children Anand and Savi both make him feel worthlessness and insecurity as his stay in Hanuman House deprives him attaining an authentic image in children's eyes as they know, “. . . Mr. Biswas, like all the fathers at Hanuman House, had come from nothing, and the only people who had a proper family were the Tulsis" (367). The wish to become a perfect father instills in Mr. Biswas to continue his search for identify that pushes him towards various displacements. Thus, Naipaul creates a world of, "Homeless nomadic migrants making middle passages from Africa or India to the West Indies thence to England and back again, for, after three hundred years there is no society and no system of values in which they can take root" (Oremerod162).

Mr. Biswas's fear of identity also related to the wish to escape from inherited class identity as a labourer, “. . . he became once more only a labourer's child-father's occupation: labourer was the entry in the 
birth certificate. .."(48). The constant social pressures through various working experience under Tulsi in Chase and Green Vale make him insecure and he "thought of estate-driver, exalted it overseer, rejected it, and rejected shopkeeper, rejected unemployed" (338). The continuous dependency on Tulsi reminds inferiority of his lowest class, while his attempt to achieve high class status end in failure and self imprisonment, "...at the end he returned to his crowded, shabby room" (48). The role of adjustment in the adverse situations does not free him from alienation as Gorden Rohlehr finds his actual condition in an alien land:

Biswas is everyman wavering between identity and non-entity,... he is fully presented as a person whose very quick and idiosyncrasy we know in the world where every sight sound and smell recorded with fidelity and precision (IA 137-38).

Living at Shorthill, Mr. Biswas buys an isolated piece of land and constructs a house, but, "The new house imprisoned them in silence and bush. They had no pleasures . .." (448). Though Mr. Biswas takes this new house as a personal achievement, but this attempt ends in futility as the house destroys one night in a fire and the episode of failure repeats, as A.C. Derrick observes, “. . . the recurring images of darkness decay and death makes . . . failure appear throughout as the inheritable outcome of Biswas struggle" (NTN 201). Biswas's last time spends in despair as his total saving is less to buy a house. He finally borrows money and buys a house at Sikkim Street and achieves his goal. Though, this symbolic goal of search for independence, identity and security fulfilled, but at cost of lost energies both physical and mental. After entering in the house, he falls ill. $\mathrm{He}$ is cheated by the solicitor's clerk who sells fragile house, "The staircase was dangerous; the upper floor sagged; there was no Black door; most of the windows didn't close; one door could not open ..." (6). Though it is in bad shape but symbolizes Mr. Biswas's, ". . . a new, readymade world" (7).However this house fulfills his life-long struggles and it represents, “. . . the story of a man's struggle to make something valuable out of circumscribed and mediocre existence. It is a struggle symbolized by the hero's effort to own his house, which in a way, is to own his own life" (Ramadevi 52). His life spends in achieving two things in life; first a 'house' through which he fulfills the desires of Savi's doll's house and second is a 'Car' which is asked by Anand in earlier time as a gift. Both things symbolize social 'name' 'fame' and 'security'.

The concluding part of the novel continues with the inheriting wish of identity and insecurity that shifts from one generation to next. The search for same cause continues in Mr. Biswas's son, Anand who goes abroad and becomes the victim of same socio-cultural disparities and mental depression as his fathers had in past. He does not live with Mr. Biswas in the last time, and his struggle becomes replica of his father's past. With the identical end of past and present, author draws readers' attention to the autobiographical aspects of his life in Trinidad and out of Trinidad. The life of Biswas and Anand reminds readers the heritage of the author that he receives from the traumatic experience of his father's life; and it shapes his vision, "What Naipaul has done .. . has been to abstract from his father's life not a sequence of events but a quality of experience which he has shaped in such a way as to project his own vision its significance" (White 96).

Alike Naipaul, Mr Biswas's alienation deprives him attaining stable identity thus, always keeps his journey to find a secure place in a Creole world. It symbolizes an individuals' search in post- colonial society. In this way, the text focuses on the dilemma of the rootless person whose quest reflects expatriates suffering from basic necessities in colonial world. Biswas's house in Sikkim Street provides him self-realization of confirmed security and identity but with ironical ends. Fawzia Mustafa describes, "Biswas's career as a journalist and his acquisition of the house on Sikkim Street signify with a mixture of poignancy and dramatic irony the depleted potentialities of post colonial independence complete with its self delusions" (VSN 62).

\section{Works Cited}

[1]. Das, B.K. "From Slavery to Freedom: A Study of V.S. Naipaul's A House for Mr. Biswas." Aspect of Commonwealth Literature. New Delhi: Creative Books, 1995.

[2]. Derrik, A.C. "Naipaul's Technique as a Novelist." Critical Perspective on V.S. Naipaul . Ed. Robert B. Hamner. Washington D.C: Three Continent, 1977.

[3]. Mustafa, Fawzia. V.S. Naipaul. Cambridge: Cambridge University Press, 1975.

[4]. Naipaul V.S. A House for Mr. Biswas. 1961. Rpt.London: Picador, 2005.

[5]. Ormerod, David. "In a Derelict Land: The Novels of V.S. Naipaul." Critical Perspectives on V.S. Naipaul. Winter.1968.

[6]. Ramadevi, N. The Novels of V.S. Naipaul: Quest for Order and Identity, New Delhi: Mehta Offset Press, 1996.

[7]. Hamner, Robert. "Character and Setting." Critical Perspectives on V.S. Naipaul. Washington D.C: Three Continent, 1979.

[8]. Rohlehr, Gorden. "Ironic Approach: The Novel of V.S. Naipaul." The Island in Between. Ed.Louis James. London: Oxford University Press, 1968.

[9]. Walsh, William. A Manifold Voice: Studies in Commonwealth Literature .London: Chatto and Indus, 1970.

[10]. White, Landeg. V.S. Naipaul: A Critical Introduction. London: Macmillan, 1975. 